\title{
Effectiveness of Solar Driven Anodic Oxidation and Uv Methods for Disinfection of Municipal Wastewater in India
}

\author{
Roopak Varshney, Nadeem Khalil
}

\begin{abstract}
This paper presents the performance of the two disinfection methods experimented at a pilot scale level as part of an integrated treatment system involving Anaerobic Digestion (UASB Process) followed by the Constructed Wetlands (CW) for municipal wastewater treatment under Indian conditions. The disinfection methods were installed in parallel at a pilot scale levels involving solar driven Anodic Oxidation (AO) and Ultra-violet $(U V)$. The systems were implemented within the Indo-Euro Research Project "SWINGS" at three places in India namely, Aligarh, Kalyani and Amarkantak, with aim to develop / deploy sustainable wastewater management. This study mainly focused on three microbial groups, total coliforms (TC), fecal coliforms (FC) and E-coli. Both the systems, $A O$ and $U V$ were operated at a very less energy demand. This was in the range 0.25 to $0.30 \mathrm{kWh} / \mathrm{m3}$. The energy requirements was met with the help of roof top solar panels. The raw municipal wastewater contained TC, FC and E. coli in the range of 105 to $107 \mathrm{CFU} / 100 \mathrm{ml}$. It was found that about 3-log unit indicator organisms were removed in the UASB \& CWs. The effluent of CWs were equally fed to the two parallel disinfection systems, $A O$ and $U V$. Results indicate that $U V$ has shown better performance. The final effluent of $A O$ contains average (TC 42.0 \pm 39.2, FC 16.1 \pm 13.2 , E-coli 5.6 \pm 6.3$)$ CFU/100 $\mathrm{ml}$ whereas $U V$ effluent was TC 6.6 \pm 4.1, FC 1.2 \pm 1.0 , E-coli $0.1 \pm 0.3 \mathrm{CFU} / 100 \mathrm{ml}$. The study concludes that solar driven disinfection systems like $A O$ and $U V$ are very effective for small flow rates and offers a promising way to energy scarce regions or in remote areas.
\end{abstract}

Keywords: Disinfection, Solar energy, Coliforms, Anodic Oxidation, Municipal Wastewater

\section{INTRODUCTION}

Disinfection is an integral part of any municipal wastewater treatment system. It involves inactivation or killing pathogenic microorganisms of the secondary effluent which may otherwise cause direct impact on human health and receiving water body [1], [2]. In developing countries like India chlorination is considered as the most conventional way of disinfection because of its cost-effectiveness, and simple to use [3]. However, in several studies it shows that chlorination in presence of high organic carbon in water produces

Manuscript published on November 30, 2019

* Correspondence Author

Roopak Varshney*, Civil Engineering Department, Aligarh Muslim University, Aligarh, India.

Nadeem Khalil, Civil Engineering Department, Aligarh Muslim University, Aligarh, India.

(C) The Authors. Published by Blue Eyes Intelligence Engineering and Sciences Publication (BEIESP). This is an open access article under the CC-BY-NC-ND license http://creativecommons.org/licenses/by-nc-nd/4.0/ unacceptable levels of Halo-acetic acids (HAA), Trihalomethanes (THM) and other carcinogenic by-products [4]. During recent past, many new disinfection methods have been developed. Each method has its own merits and demerits. One of the disinfection methods commonly used is UV. Recently, another emerging technique is electro-chemical (EC) commonly called as 'Anodic oxidation'. Both the systems are energy driven with almost no bi-products. However, with advancement, these systems can also be operated by solar driven power that makes the technology more attractive proposition from self-sustainable point of view [5], [6]. The main advantage of the electro-chemical disinfection is the production of on-site disinfectants from chlorides present in the water [7]-[9]. Literature suggest that inactivation of micro-organisms through EC is achieved through various mechanism; this includes electro-chlorination, destruction caused by the electric field and inactivation by intermediate products [10]. The free radicals produced during EC process, such as O2-, $\mathrm{OH}-, \mathrm{HClO}-$, and $\mathrm{ClO} 2-$ which plays an important role in disinfecting the water. [11] The inactivation efficacy of electrochemical disinfection systems is largely dependent on, electrode material, electrolyte composition, cell configuration and other experimental parameters, such as flow rate and current density [12] Another disinfection method which is also gaining large popularity is Ultraviolet (UV), as it doesn't produce any by-product, no odor, and considered to be more safe and easy in operations [13], [14]. UV light emitted by mercury arc-lamps (low or medium pressure), is effective against a variety of pathogenic microorganisms including viruses, bacteria and protozoan cysts [15]-[17]. The objective of this study was to assess and investigate the effectiveness of the two disinfection systems, AO and UV, using the same feed (water quality) that was sourced from the final outlet of the constructed wetlands for municipal wastewater at a pilot scale level. 


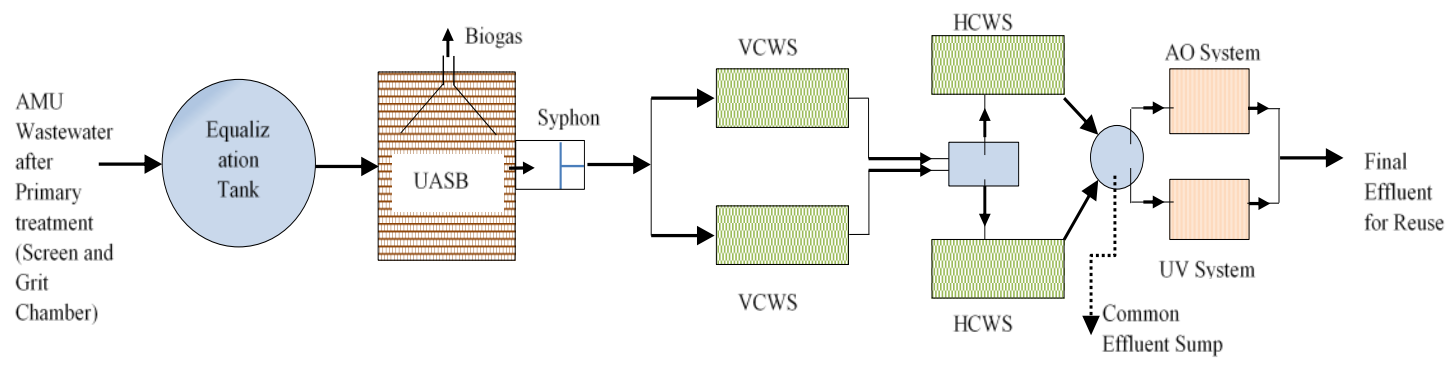

Fig. 1. Flow diagram of SWINGS pilot plant, AMU, India

\section{METHODOLOGY}

\section{A. Pilot Plant and Monitoring}

The study was performed at a pilot scale level at Aligarh, India under a major collaborative research programme "SWINGS" supported by the Government of India and European Commission within FP7 Framework. It was led by the Aligarh Muslim University (AMU), Aligarh as Indian Coordinator. The AO and UV systems were installed in the last stage of the treatment train involving anaerobic digestion (UASB) and two-stage Constructed Wetlands (Vertical flow and Horizontal Flow). A fraction of the raw sewage (municipal wastewater) from AMU campus was taken on continuous basis to this pilot plant located within AMU campus at Aligarh, India. The treated effluent from CWs undergoes through the disinfection systems (AO and UV) installed in parallel. The flow diagram of SWINGS Pilot Plant is given in Fig.1. The AO and UV systems installed at this plant is shown in Fig.2. In this study, the monitoring of the two disinfection systems were performed for indicator organisms which include total coliforms, feacal coliforms and e-coil at inlet and outlet points at each stage. The study was started in January 2017 and ended in November 2017. All the microbiological parameters were analyzed twice a week. Total coliforms, fecal coliforms, and E-coli were determined by the membrane filtration technique, using $0.45 \mu \mathrm{m}$ pore-size filters (Merck) and selective agars: Chromocult-coliform agar (Merck) for E. coli and TC bacteria whereas $\mathrm{m}-\mathrm{FC}$ agar (Hi media) for fecal coliform bacteria (APHA, 2012). Quality of feed water to AO system were also monitored by analyzing parameters; Chemical Oxygen Demand (COD), Biochemical

Oxygen Demand (BOD), Total Suspended Solids (TSS), Total Kjeldahl Nitrogen (TKN), hardness and chlorides. All these parameters were determined in accordance to the APHA, 2012.

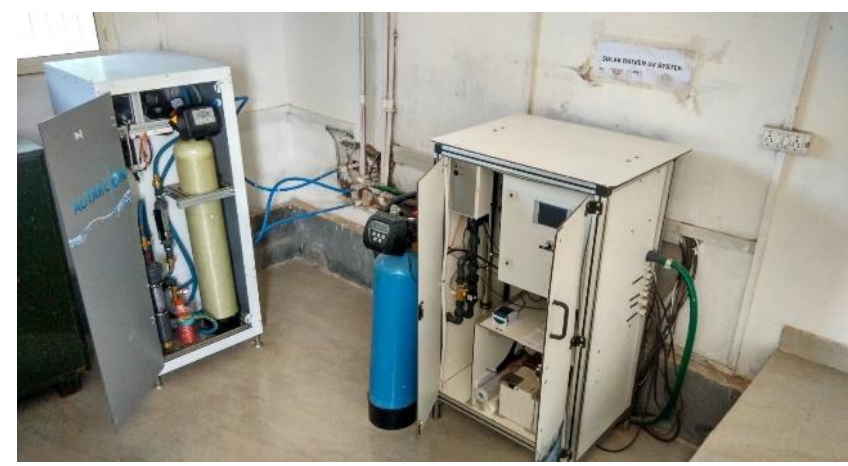

Fig. 2. Picture of AO \& UV systems installed at SWINGS Pilot Plant AMU, Aligarh

\section{RESULT AND DISCUSSION}

The treatment plant was continuously monitored for ten months after its commissioning. The average physical -chemical parameters with standard deviation of raw sewage and both constructed wetlands effluents (in $\mathrm{mg} / \mathrm{l}$ ) are given in Table- I.

Table- I: Characteristics of Inlet \& Outlet at different stages of the SWINGS pilot plant

\begin{tabular}{|c|c|c|c|c|c|}
\hline S.no & Parameter & Raw Sewage & UASB & After V-CW & After H-CW \\
\hline 1. & Turbidity (NTU) & $58.8 \pm 24.6$ & $29.1 \pm 10.2$ & $1.5 \pm 0.59$ & $1.1 \pm 0.5$ \\
\hline 2. & COD (mg/l) & $264.5 \pm 45.1$ & $123.2 \pm 16.9$ & $15.4 \pm 12.7$ & $10.3 \pm 8.6$ \\
\hline 3. & BOD (mg/l) & $116.9 \pm 17.5$ & $59.6 \pm 9.4$ & $4.02 \pm 1.9$ & $2.67 \pm 1.68$ \\
\hline 4. & TSS (mg/l) & $183.1 \pm 18.4$ & $65.3 \pm 12.7$ & $2.5 \pm 2.1$ & $1.9 \pm 2.68$ \\
\hline 5. & TKN (mg/l) & $33.02 \pm 4.7$ & $25.8 \pm 5.6$ & $1.1 \pm 0.88$ & $0.3 \pm 0.65$ \\
\hline 6. & Hardness (mg/l) & $329.36 \pm 33.9$ & $325 \pm 30.1$ & $339.2 \pm 24.6$ & $344.7 \pm 34.5$ \\
\hline 7. & Chlorides (mg/l) & $104 \pm 9.1$ & $103 \pm 12.2$ & $103.7 \pm 9.4$ & $102.9 \pm 8.9$ \\
\hline
\end{tabular}




\begin{tabular}{|c|c|c|c|c|c|}
\hline 8. & TC & $\begin{array}{c}1.41 \mathrm{E}+07 \pm \\
9.60 \mathrm{E}+06\end{array}$ & $\begin{array}{c}1.1 \mathrm{E}+06 \pm \\
5.60 \mathrm{E}+06\end{array}$ & $\begin{array}{c}3.67 \mathrm{E}+04 \pm \\
2.3 \mathrm{E}+03\end{array}$ & $\begin{array}{c}2.07 \mathrm{E}+04 \pm \\
1.67 \mathrm{E}+04\end{array}$ \\
\hline \multirow{2}{*}{9.} & FC & $3.87 \mathrm{E}+06 \pm$ & $7.7 \mathrm{E}+05 \pm$ & $8.3 \mathrm{E}+03 \pm$ & $4.78 \mathrm{E}+03 \pm$ \\
& & $2.56 \mathrm{E}+06$ & $8.6 \mathrm{E}+05$ & $2.34 \mathrm{E}+03$ & $4.14 \mathrm{E}+03$ \\
\hline \multirow{2}{*}{10.} & \multirow{2}{*}{ E-Coli } & $1.17 \mathrm{E}+06 \pm$ & $4.1 \mathrm{E}+05 \pm$ & $2.6 \mathrm{E}+03 \pm$ & $1.32 \mathrm{E}+03 \pm$ \\
& & $7.76 \mathrm{E}+05$ & $3.6 \mathrm{E}+05$ & $3.2 \mathrm{E}+03$ & $1.12 \mathrm{E}+03$ \\
\hline
\end{tabular}

\section{V-CW Vertical Flow Constructed Wetlands}

\section{H-CW Horizontal Flow Constructed Wetlands}

The overall efficiency of the treatment plant for indicator organisms involving secondary stage and AO and UV system is summarized in Fig. 3a, 3b, and 3c. The graphs show the concentration of three pathogenic indicator microorganisms (TC, FC and E-coli) monitored during the course of study. It has been observed that the reduction rate of coliform bacteria is slightly higher in cold as compared to the warm weather conditions. This may be attributed to bacteria becoming less resistive in cold conditions for disinfection [14]. The Average values for indicator organisms in $\mathrm{AO}$ effluent are (TC

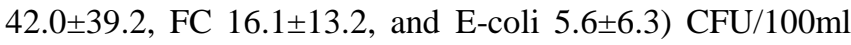
whereas for UV effluents values are (TC 6.6 $\pm 4.1, \mathrm{FC} 1.2 \pm 1.0$, and E-coli $0.1 \pm 0.3) \mathrm{CFU} / 100 \mathrm{ml}$.

Additionally, few peaks in the AO effluent quality were also observed. The reason is in concurrence to the findings of [18], [19] which mentions calcium deposits at electrolytic cell slows down the process of chlorine formation and hence the removal rate of coliforms. Graph shows that fecal coliform and E-coli bacteria in the UV effluent were several times found zero or less than $5 \mathrm{CFU} / 100 \mathrm{ml}$.

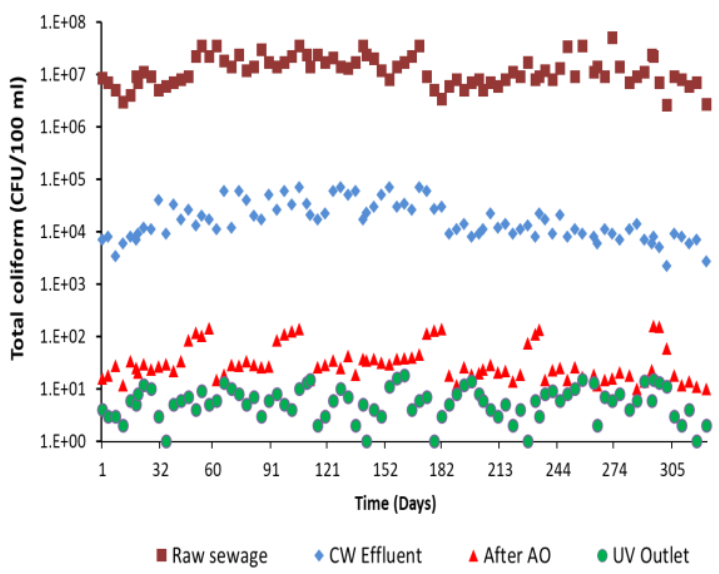

Fig. 3. (a)

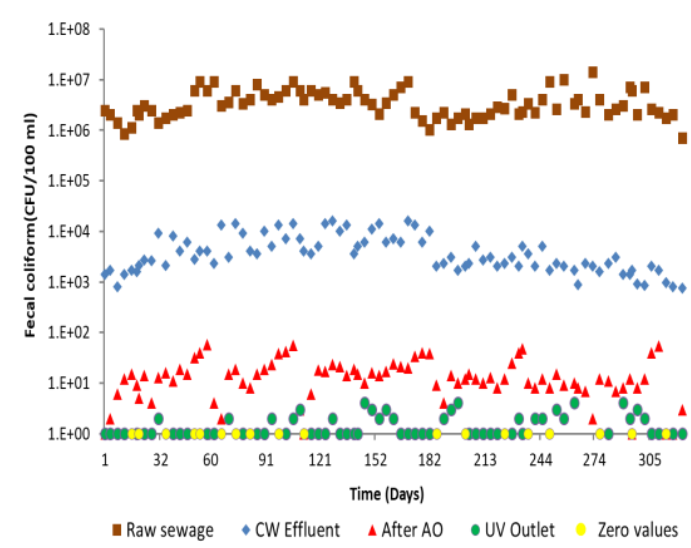

Fig. 3. (b)

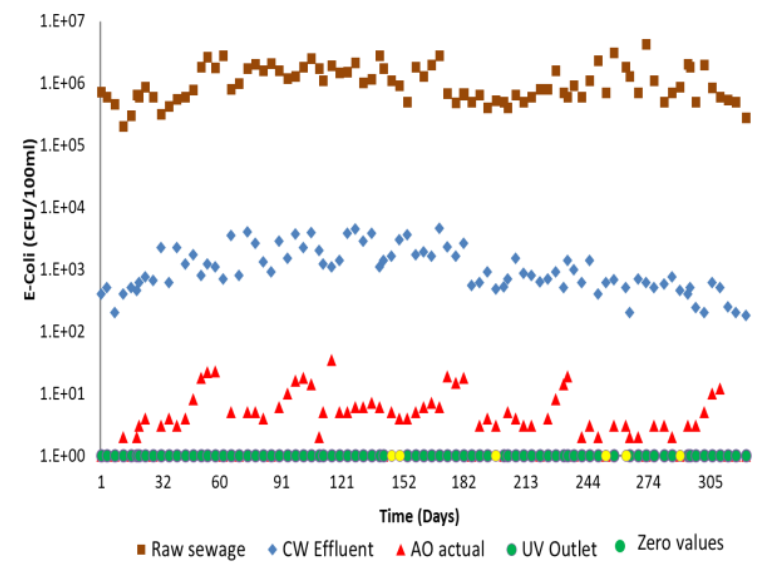

Fig. 3. (c)

Fig. 3 Shows graph between concentration of (a) FC (b) TC and (c) E-coli (CFU/100ml) in AO and UV outlet with respect to time (days).

\section{CONCLUSION}

Based on the findings of the study, significant removal of TC, FC and E-coli has been observed which indicates that anodic oxidation and UV works quite effectively. When using solar panels for their energy demand, the whole concept of integrated treatment system becomes self-sustainable. The final effluent quality after $\mathrm{AO}$ or UV meets the discharge norms far below the standards and thus it can be concluded that these systems are effective and one of the most promising ways to disinfect municipal wastewater.

\section{ACKNOWLEDGMENT}

The authors would like to acknowledge the Department of Science \& Technology, Government of India and European Commission for their financial support to the project "SWINGS" within Indo-Euro Water Technology Programme under FP7 Framework. The logistics and infrastructure support provided by the Aligarh Muslim University, India to set-up the pilot plants for this collaborative project deserves high appreciation.

\section{REFERENCES}

1. H. Li, X. Zhu, and J. Ni, "Electrochimica Acta Comparison of electrochemical method with ozonation, chlorination and monochloramination in drinking water disinfection," Electrochim. Acta, vol. 56, no. 27, pp. 9789-9796, 2011.

2. M. D. Gómez-López, J. Bayo, M. S. García-Cascales, and J. M. Angosto, "Decision support in disinfection technologies for treated wastewater reuse," J. Clean. Prod., vol. 17, no. 16, pp. 1504-1511, 2009.

3. M. J. Nieuwenhuijsen, M. B. Toledano, N. E. Eaton, J. Fawell, and P. Elliott, "Chlorination disinfection byproducts in water and their association with adverse reproductive outcomes : a review," pp. 73-85, 2000 . 
4. S. Tak and A. Kumar, "Chlorination disinfection by-products and comparative cost analysis of chlorination and UV disinfection in sewage treatment plants : Indian scenario," 2017.

5. P. Go, R. Iban, I. Ortiz, A. M. Urtiaga, and G. Pe, "Electrochemical disinfection of secondary wastewater treatment plant (WWTP) effluent," pp. 892-897, 2010.

6. J. Zheng, C. Su, J. Zhou, L. Xu, Y. Qian, and H. Chen, "Effects and mechanisms of ultraviolet, chlorination, and ozone disinfection on antibiotic resistance genes in secondary effluents of municipal wastewater treatment plants," vol. 317, pp. 309-316, 2017.

7. V. Kumar et al., "Application of horizontal fl ow constructed wetland and solar driven disinfection technologies for wastewater treatment in India," vol. 13, no. 3, pp. 469-480, 2018.

8. Y. Delaedt et al., "The impact of electrochemical disinfection on Escherichia coli and Legionella pneumophila in tap water," vol. 163, pp. 192-199, 2008

9. A. Kraft et al., "Electrochemical water disinfection Part I : Hypochlorite production from very dilute chloride solutions," pp. 861-868, 1999.

10. X. Y. Li, F. Ding, P. S. Y. Lo, and S. H. P. Sin, "Electrochemical Disinfection of Saline Wastewater Effluent," vol. 128, no. 8, pp. 697-704, 2003.

11. X. Huang et al., "Electrochemical disinfection of toilet wastewater using wastewater electrolysis cell," Water Res., vol. 92, pp. 164-172, 2016.

12. M. I. Kerwick, S. M. Reddy, A. H. L. Chamberlain, and D. M. Holt, "Electrochemical disinfection, an environmentally acceptable method of drinking water disinfection," vol. 50, pp. 5270-5277, 2005.

13. B. A. Madge and J. N. Jensen, "Ultraviolet Disinfection of Fecal Coliform in Municipal Wastewater: Effects of Particle Size," Water Environ. Res., vol. 78, no. 3, pp. 294-304, 2006.

14. O. M. Lee, H. Y. Kim, W. Park, T. H. Kim, and S. Yu, "A comparative study of disinfection efficiency and regrowth control of microorganism in secondary wastewater effluent using UV, ozone, and ionizing irradiation process," J. Hazard. Mater. vol. 295, pp. 201-208, 2015.

15. W. A. M. Hijnen, E. F. Beerendonk, and G. J. Medema, "Inactivation credit of UV radiation for viruses, bacteria and protozoan (oo) cysts in water: A review," Water Res., vol. 40, no. 1, pp. 3-22, 2006.

16. C. Hallmich and R. Gehr, "Effect of pre- and post-UV disinfection conditions on photoreactivation of fecal coliforms in wastewater effluents," Water Res., vol. 44, no. 9, pp. 2885-2893, 2010.

17. M. Guo, H. Hu, and W. Liu, "Preliminary investigation on safety of post-UV disinfection of wastewater: bio-stability in laboratory-scale simulated reuse water pipelines," DES, vol. 239 , no. 1-3, pp. 22-28, 2009

18. P. Otter et al., "Arsenic Removal from Groundwater by Solar Driven Inline-Electrolytic Induced Co-Precipitation and Filtration - A Long Term Field Test Conducted in West Bengal,” 2017.

19. J. Rennau, A. Kraft, M. Blaschke, D. Kreysig, B. Sandt, and F. Schro, "Electrochemical water disinfection. Part II : Hypochlorite production from potable water, chlorine consumption and the problem of calcareous deposits," no. Figure 1, pp. 895-902, 1999.

\section{AUTHORS PROFILE}

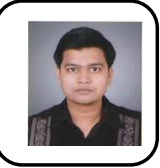

Roopak Varshney is presently $\mathrm{PhD}$ student in the Environmental Engineering Section, Department of Civil Engineering, Aligarh Muslim University (AMU), and Aligarh. He did his B.Tech in Civil Engineering and M.Tech in Engineering from AMU. He has been JRF and SRF under the project SWINGS for a period of two years. He has also been involved in the joint inspection of grossly polluting industries as part of the sponsored project from the Central Pollution Control Board, Delhi. Under SWINGS, he had been to Aarhus University, Denmark for learning new tools and techniques in the field of wetlands technology.

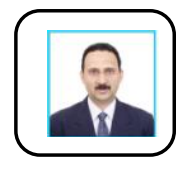

Nadeem Khalil is a Professor in the Department of Civil Engineering at Aligarh Muslim University (AMU), Aligarh, India. He did his PhD from IIT Delhi, M. Tech (Env Engineering) \& B.Tech (Civil Engg) from AMU. Prior to academic, he has served as an Environmental Engineer in a consulting firm based in New Delhi. His research interests are mainly focussed on novel wastewater treatment technologies \& processes, energy from short-rotation forestry, and waste management issues. Most of his research activities are in collaboration with leading International institutions, with funding from national and International agencies like European Commission, Japan International Cooperation Agency (JICA), and Japan for Science \& Technology, 2030 WRG, Department of Science \& Technology, and Central Pollution Control Board, Government of India. He has an excess of 25 peer reviewed research publication. 